\title{
Influence of high-resolution data on the assessment of forest fragmentation
}

\author{
J. Wickham (1D) K. H. Riitters
}

Received: 13 December 2018/ Accepted: 15 April 2019/Published online: 25 May 2019

(C) The Author(s) 2019

\begin{abstract}
Context Remote sensing has been a foundation of landscape ecology. The spatial resolution (pixel size) of remotely sensed land cover products has improved since the introduction of landscape ecology in the United States. Because patterns depend on spatial resolution, emerging improvements in the spatial resolution of land cover may lead to new insights about the scaling of landscape patterns.

Objective We compared forest fragmentation measures derived from very high resolution $\left(1 \mathrm{~m}^{2}\right)$ data with the same measures derived from the commonly used (30 $\left.\mathrm{m} \times-30 \mathrm{~m} ; 900 \mathrm{~m}^{2}\right)$ Landsat-based data.

Methods We applied area-density scaling to binary (forest; non-forest) maps for both sources to derive source-specific estimates of dominant (density $\geq 60 \%$ ), interior ( $\geq 90 \%$ ), and intact $(100 \%)$ forest.

Results Switching from low- to high-resolution data produced statistical and geographic shifts in forest spatial patterns. Forest and non-forest features that
\end{abstract}

J. Wickham ( $\square)$

National Exposure Research Laboratory, Office of Research Development, U.S. Environmental Protection Agency, 109 T.W. Alexander Dr.; MD: 343-05, Research Triangle Park, NC 27711, USA e-mail: wickham.james@epa.gov

\section{K. H. Riitters}

Southern Research Station, United States Department of Agriculture, Forest Service, Research Triangle Park,

NC 27709, USA were "invisible" at low resolution but identifiable at high resolution resulted in higher estimates of dominant and interior forest but lower estimates of intact forest from the high-resolution source. Overall, the high-resolution data detected more forest that was more contagiously distributed even at larger spatial scales.

Conclusion We anticipate that improvements in the spatial resolution of remotely sensed land cover products will advance landscape ecology through reinterpretations of patterns and scaling, by fostering new landscape pattern measurements, and by testing new spatial pattern-ecological process hypotheses.

Keywords Chesapeake Bay land cover - Forest spatial patterns $\cdot$ NLCD $\cdot$ Spatial resolution remote sensing

\section{Introduction}

Landscape ecology was born out a new technologyremote sensing. Carl Troll (1899-1975) is credited with the insight because of his observation that the image in an aerial photograph was a picture of an ecosystem (Troll 1971). As he points out in his 1971 paper, Troll introduced the concept of landscape ecology in 1939 (Troll 1939; see also Butzer 2004). Aerial photography was emerging as a new technology 
in 1939, recognized for its military applications and, somewhat later, for its academic value (Estes et al. 1980).

Landscape ecology found its way to the United States by the 1980s (Risser et al. 1984), and similarly relied on remotely sensed data to articulate its main concepts. Indices of landscape pattern (O'Neill et al. 1988), still the most-cited paper in the journal Landscape Ecology (Wu 2013), used digital land cover maps derived from interpretation of aerial photography to show how measures commonly applied in ecological field studies (e.g. Brower and Zar 1977) could be used to provide ecological insight over a much broader geographic area using a domain of ecological organization other than species. The paper stimulated an enthusiastic investigation of landscape pattern, including a wide array of pattern measurements as well as software to calculate the measurements (Turner et al. 1989; Baker and Cai 1992; McGarigal and Marks 1995; Riitters et al. 1995)

Remote sensing advanced as landscape ecology developed. The paper by O'Neill et al. (1988) used land cover from the U.S. Geological Survey (USGS) Land Use Data Analysis (LUDA) program. LUDA was based on high-altitude aerial photography that had a 4-ha minimum mapping unit (mmu) for urban classes and a 16-ha mmu for all other classes (Loveland 2012). The data were eventually converted to raster format (Loveland 2012) at a 4-ha $\mathrm{pixel}^{-1}$ spatial resolution (Fegeas et al. 1983). The raster formatted LUDA data were the basis of the research reported by O'Neill et al. (1988) and others (e.g., Riitters et al. 1995; Turner et al. 1989). By the late 1990s, through the formation of the multi resolution land characteristics (MRLC) consortium (Homer et al. 2004; Wickham et al. 2014; Yang et al. 2018), remote sensing of land cover had advanced to producing land cover for the conterminous United States from the Landsat satellite series (Vogelmann et al. 2001; Homer et al. 2007), which had a native resolution of 0.09 ha pixel $^{-1}$. The $4500 \%$ increase in spatial resolution increased confidence in the assumption of homogeneity for a pixel's land cover class label and obviated the need for "mixed" classes (e.g., cropland and natural vegetation) that were typically necessary at coarser spatial resolutions (e.g., Loveland et al. 2000). The wider availability of higher resolution land cover data permitted more meaningful measurements of landscape patterns for riparian zones, urban areas, and feature (e.g., forest) connectivity (Jones et al. 1997; Wickham et al. 1999). Examples of new insights attributable to the availability of higher resolution land cover data distinguished forest edge, interior, and perforations for the conterminous United States (Heilman et al. 2002; Riitters et al. 2002). The higher resolution permitted more accurate overlays with ancillary data such as road maps (Heilman et al. 2002) and better characterization of the components of fragmentation (Riitters et al. 2002). The pattern metrics derived from the land cover data were subsequently included in national ecological assessments such as the Montréal Process (Riitters et al. 2004) and Heinz Center (2008).

Nearly two decades have passed since measurement of landscape indicators from Landsat-based land cover maps became commonplace, and we may be on the cusp of another significant technological advance. The United States Department of Agriculture (USDA), Farm Service Agency (FSA) now provides raster images at $1 \mathrm{~m}^{2}$ spatial resolution for the United States through its National Agriculture Imagery Program (www.fsa.usda.gov/programs-and-services/ aerial-photography/imagery-programs/naip-imagery/). Use of NAIP imagery for land cover mapping and other applications is widespread (Popkin 2018). In addition, the National Oceanic and Atmospheric Administration (NOAA), Coastal Change Analysis Program (C-CAP) plans to map land cover from NAIP for the coastal portions of the United States (N. Herold pers. comm.; coast.noaa.gov/digitalcoast/data/), and NAIP-based land cover is available for about $25 \mathrm{U}$. S. metropolitan areas through the Environmental Protection Agency (EPA), EnviroAtlas project (www.epa. gov/enviroatlas). Because of ever-increasing computing capability (both desktop and cloud) and continued advances in remote sensing technology, it is likely that land cover from high resolution sources will become the preferred choice in the future, replacing land cover data from Landsat and similar satellites (e.g., Sentinel-2).

The objective of this paper is to provide a glimpse into that future as it relates to measurement of landscape pattern. We compare measurements of forest fragmentation (Riitters et al. 2002) derived from high- $\left(1 \mathrm{~m}^{2}\right.$ pixel $\left.^{-1}\right)$ and low-resolution $\left(900 \mathrm{~m}^{2}\right.$ pixel $^{-1}$ ) data (hereafter, fine grain and coarse grain, respectively). NLCD 2011 land cover data (Homer et al. 2015) were used as the coarse-grain 
dataset and land cover data derived from NAIP for the Chesapeake Bay region (chesapeakeconservancy.org/ conservation-innovation-center/high-resolution-data/ land-cover-data-project/) were used as the fine-grain (i.e., $1 \mathrm{~m}^{2}$ pixel $^{-1}$ ) dataset. The behavior of landscape pattern measures across a range of grain sizes has been the topic of several studies (e.g., Turner et al. 1989; Corry and Lafortezza 2007; Buyantuyev et al. 2010; $\mathrm{Wu}$ 2013). Here we specifically test the assertion in Riitters et al. (2002) that forest fragmentation would be more severe if the analysis had been undertaken with finer grain land cover data. The rationale was that the greater detail available from a finer grain will improve detection of interruptions in the forest canopy, thereby reducing forest density where forest is abundant, and, by extension, increase forest density where forest is less abundant. The shift in forest patterns expected from improved spatial resolution has broad implications for landscape assessments and ecological interpretation of landscape data. Notwithstanding map accuracy issues, more perforated interior forest, realized from an assessment based on finer grain data (Foreman 1995), may trigger changes in forest management locally or regionally (Riitters et al. 2018). Similarly, increases in the amount of forest in exurban to urban contexts may have implications for water quality management (Claggett et al. 2013) and spatial variation in the magnitude of the urban heat island (UHI) effect (Quattrochi and Ridd 1996).

The concept of "forest" is both intuitive and ambiguous. Comparison of fragmentation from $1 \mathrm{~m}^{2}-$

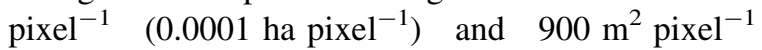
( 0.09 ha pixel $\left.^{-1}\right)$ land cover data may be questioned because the grain size of the former represents individual trees rather than forests. However, definitions of what constitutes a "forest" depend on the objective of the assessment or analysis (Chazdon et al. 2016). Not all definitions of forest include a minimum area, and those that do are not consistent in their minimum area threshold. Our view is that the comparison is valid because forest minimum area criteria vary with the ecological question (Kapos 1989; Wiens and Milne 1989). Furthermore, the minimum area criterion for the UN Framework Convention on Climate Change (UNFCCC) is 0.05 ha (Chazdon et al. 2016), and the remote sensing rule-of-thumb is that the spatial resolution of the sensor must be smaller than a feature for it to be detected accurately (https://www.nrcan.gc.ca/node/
9407). Thus, a sensor with a 0.0001 ha pixel $^{-1}$ spatial resolution would be more appropriate than a sensor with a 0.09 ha pixel $^{-1}$ to map forests as small as 0.05 ha.

\section{Methods}

Comparison of forest fragmentation measurements from fine- and coarse-grain land cover datasets was undertaken in the $248,000 \mathrm{~km}^{2}$ Chesapeake Bay region (Fig. 1) because of the availability of NAIPbased $\left(1 \mathrm{~m}^{2}\right)$ land cover (see URL in the "Introduction"). The fine-grain land cover mapping effort was sponsored by the Chesapeake Bay Program (www. chesapeakebay.net) to support improved water-quality modeling of the Chesapeake Bay. The six-class dataset, produced from 2013 NAIP imagery and ancillary data, included water, barren, tree canopy and shrubs, herbaceous, impervious (roads), and impervious (other). User's and producer's accuracies for the tree canopy and shrubs class were $83 \%$ and $81 \%$, respectively (Pallai and Wesson 2017). The NLCD 2011 land cover data, nominally 2 years older than the Chesapeake Bay land cover data, were clipped and aligned to the Chesapeake Bay land cover dataset for the comparison. The pixels in both land cover datasets were then reclassified into forest and non-forest (forest $=1$; non-forest $=0$ ). The forest class for the Chesapeake Bay land cover data was the tree canopy and shrub class; all other classes were masked (set to null). Deciduous forest, evergreen forest, mixed forest, and woody wetlands comprised the forest class the NLCD 2011 land cover. User's and producer's accuracies for the NLCD 2011 three upland forest classes were 94\% and $88 \%$, respectively, and the corresponding values for the woody wetlands class were $74 \%$ and $87 \%$, respectively (Wickham et al. 2017). Total forest area was approximately $16.4 \times 10^{6}$ ha based on the finegrain (Chesapeake Bay) land cover data and $14.8 \times 10^{6}$ ha for the coarse-grain (NLCD) land cover data.

We used forest density ( $\mathrm{Fd})$ as our measure of forest fragmentation. Forest density was estimated for five window sizes using the binary (forest or non-forest) land cover maps by summing the number of pixels labeled as forest in a given window and assigning the result to the center pixel in the window. The square window side lengths in meters (m) were 150, 270, 810, 


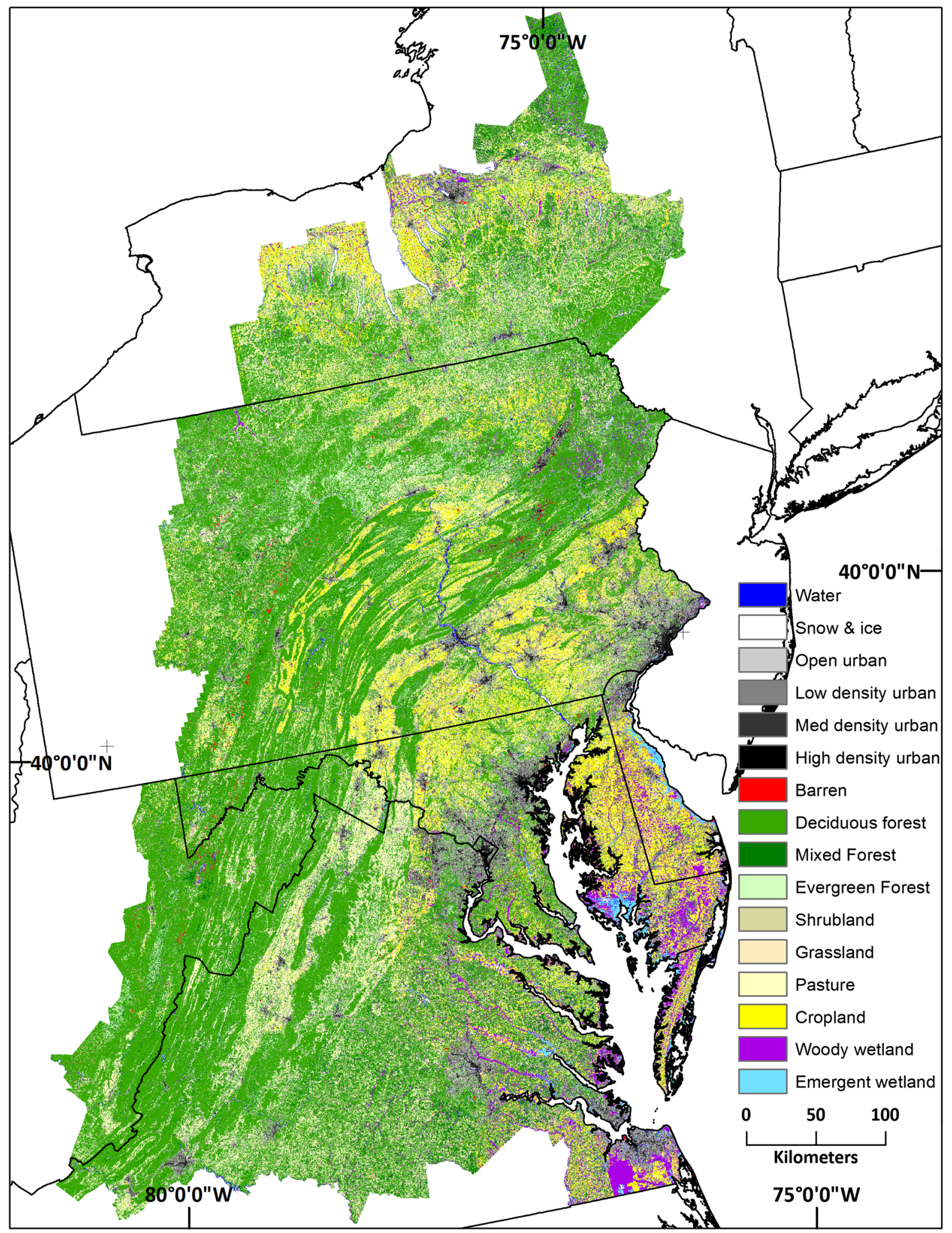

Fig. 1 NLCD 2011 land cover for the Chesapeake Bay region 
Table 1 (A) Fine- minus coarse-grain forest area difference (ha) and (B) coarse-grain forest area

\begin{tabular}{|c|c|c|c|c|c|}
\hline \multirow[t]{2}{*}{ Forest density (\%) } & \multicolumn{5}{|l|}{ Spatial scale } \\
\hline & 2.25 ha & 7.29 ha & 65.61 ha & 590.49 ha & 5314.41 ha \\
\hline \multicolumn{6}{|l|}{ (A) } \\
\hline$\geq 40$ & $2,083,356$ & $2,285,500$ & $2,522,520$ & $2,682,915$ & $3,255,486$ \\
\hline$\geq 50$ & $2,064,895$ & $2,202,949$ & $2,409,862$ & $2,554,352$ & $3,185,795$ \\
\hline$\geq 60$ & $1,865,597$ & $2,100,951$ & $2,267,121$ & $2,447,152$ & $2,794,899$ \\
\hline$\geq 70$ & $1,920,957$ & $1,963,893$ & $2,096,673$ & $2,267,732$ & $2,583,227$ \\
\hline$\geq 80$ & $1,600,523$ & $1,801,353$ & $1,852,927$ & $1,830,003$ & $1,724,465$ \\
\hline$\geq 90$ & $1,547,598$ & $1,670,675$ & $1,500,392$ & $1,193,555$ & 933,480 \\
\hline$\geq 95$ & 896,156 & $1,252,675$ & $1,289,377$ & 807,657 & 499,474 \\
\hline 100 & $-1,341,996$ & $-1,259,004$ & $-694,544$ & $-36,622$ & 0 \\
\hline \multicolumn{6}{|l|}{ (B) } \\
\hline$\geq 40$ & $13,515,224$ & $13,121,687$ & $12,539,116$ & $12,198,415$ & $11,960,452$ \\
\hline$\geq 50$ & $13,108,508$ & $12,640,428$ & $11,790,328$ & $11,245,707$ & $10,920,015$ \\
\hline$\geq 60$ & $12,669,873$ & $11,938,866$ & $10,750,083$ & $9,813,411$ & $9,151,595$ \\
\hline$\geq 70$ & $11,775,833$ & $11,022,699$ & $9,390,184$ & $7,953,038$ & $6,796,658$ \\
\hline$\geq 80$ & $11,020,195$ & $9,836,200$ & $7,710,290$ & $5,837,902$ & $4,386,764$ \\
\hline$\geq 90$ & $9,568,374$ & $8,097,989$ & $5,545,623$ & $3,434,862$ & $1,803,283$ \\
\hline$\geq 95$ & $9,068,566$ & $7,100,068$ & $3,998,056$ & $1,996,101$ & 629,882 \\
\hline 100 & $8,481,661$ & $5,920,466$ & $1,811,752$ & 121,844 & 0 \\
\hline
\end{tabular}

2430 , and 7290 , which is equivalent to side lengths of $5,9,27,81$, and 243 in pixels for the NLCD 2011 land cover data. The areas of the window sizes were 2.25 ha, 7.29 ha, 65.61 ha, 590.49 ha, and 5314.41 ha, respectively. An additional $1 \mathrm{~m}$ of side length was added to each of the window sizes for the Chesapeake Bay land cover data so that windows had a clearly defined center pixel. Results are reported only for pixels labeled as forest in the original land cover maps, i.e., forest density for forested locations rather than forest density for all locations (Riitters et al. 2002).

For each forest location and at each spatial scale (window size), we report the area of forested locations meeting or exceeding eight forest density thresholds from 40 to $100 \%$ in $10 \%$ increments and $95 \%$. The range of thresholds provide a convenient and flexible means for interpreting forest connectivity and fragmentation. We used the thresholds $\geq 60 \%$, $\geq 90 \%$, and $100 \%$ to define "dominant," "interior," and "intact" forest classes, respectively. There were different levels of precision available for defining the thresholds because of the different spatial resolutions of each land cover dataset. The number of pixels for each forest density threshold at each scale was determined by multiplying the number of pixels in the window by the specified percentage and then rounding up to the next integer value when the result was a real number. Rounding up, regardless of whether the fractional portion of the threshold was greater than or equal to 0.5 , ensured that the density threshold was met.

\section{Results}

There was substantially less intact forest $(100 \%$ threshold) identified by the fine-grain land cover data across all spatial scales examined (Table 1). The substantial reduction of intact forest resulting from the change in grain size occurred even though the increase in spatial resolution resulted in an increase in total forest area (see "Methods"). At the smallest spatial scale ( $2.25 \mathrm{ha})$, the area of intact forest from the coarse-grain data exceeded the area of intact forest from the fine-grain data by more than 1.3 million hectares (Table 1). The magnitude of the differences of coarse-minus fine-grain estimates declined to approximately 36,600 ha at the 590.49ha scale, as the requirement of uninterrupted forest 


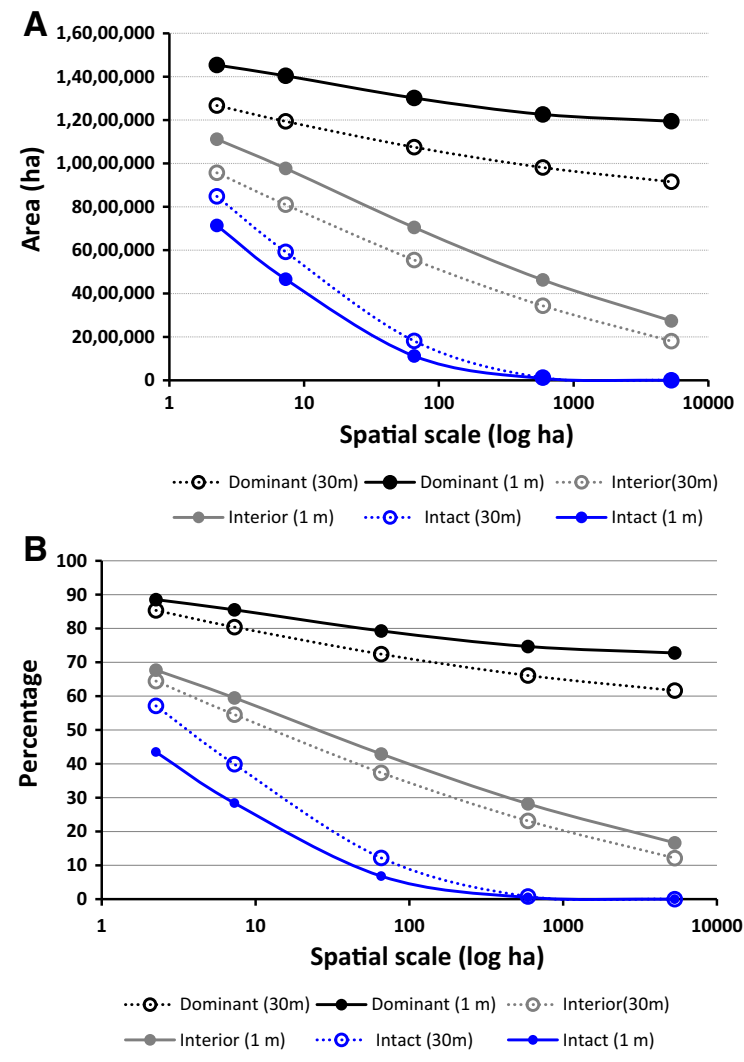

Fig. 2 Forest density class $\mathbf{a}$ area and $\mathbf{b}$ percentage at five spatial scales and two grain sizes

became harder to attain with increasing spatial scale for both coarse- and fine-grain data. Intact forest did not occur in either land cover dataset at the 5314.41ha scale.

The substantial reduction in intact forest that resulted from switching from coarse- to fine-grain land cover data was accompanied by a substantial increase in the percentage and amount of interior forest ( $\geq 90 \%$ threshold). The amount of interior forest detected using the fine-grain land cover data was greater than the amount detected by coarse-grain land cover data by more the 900,000 ha across all window sizes (Table 1). This pattern remained for a more conservative interior forest threshold ( $\geq 95 \%)$. Overall, the fine-grain estimate indicated that there was more forest that was more contagiously distributed even at larger spatial scales (Fig. 2). Excluding intact forest, the fine-grain estimates of percentage of dominant and interior forest exceeded their coarse-grain counterparts across all spatial scales.
The area differences between fine- and coarse-grain forest spatial patterns were accompanied by geographic differences. Intact forest was less predominant in the Appalachians and elsewhere in the fine-grain data because the fine-grain data detected non-forest features "invisible" to the coarse-grain data (Fig. 3). The ability of the fine-grain land cover data to detect features "invisible" to the coarse-grain data also resulted in detection of forest missed at the coarser spatial resolution, which contributed to the substantial increase in the amount of interior forest (along with a decline in intact forest) across all spatial scales (Table 1; compare Figs. 4, 5). There was a considerable amount of interior forest outside that the Appalachian region that was not detected by the coarse-grain data at the larger spatial scales (Fig. 6; compare Figs. 4, 5).

\section{Discussion}

Despite uncertainties in the future of the USDA NAIP program (Popkin 2018), it is plausible that land cover from high resolution sources will be commonplace across the United States in the near future, supplanting land cover data from Landsat and other platforms with similar spatial resolution. It is likely that such an increase in spatial resolution will influence what we see, how we measure what we see, and how we interpret what we measure (Mandelbrot 1982). In this study, using a previously established measurement method (forest density from spatial convolution), we found that use of finer grain maps influenced both what we saw and our interpretations of what we saw. By switching from coarse- to fine-grain resolution we found that forest fragmentation was less severe rather than more severe, except for the intact forest class, and that interior forest was more uniformly distributed across the region. The earlier improvement in resolu-

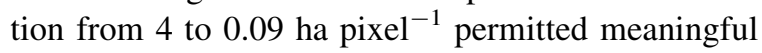
quantification of landscape features (Jones et al. 1997; Riitters et al. 2002; Vogt et al. 2007; Wickham et al. 2010) that were recognized earlier (Forman and Gadron 1986; Zipperer 1993) but less meaningful when measured using land cover data with 4-ha pixel ${ }^{-1}$ spatial grain. Apart from improved spatial precision of pattern indices, another substantial increase in spatial resolution (e.g., 0.09 ha pixel $^{-1}$ to 0.0001 ha pixel $^{-1}$ ) may result in the identification and 


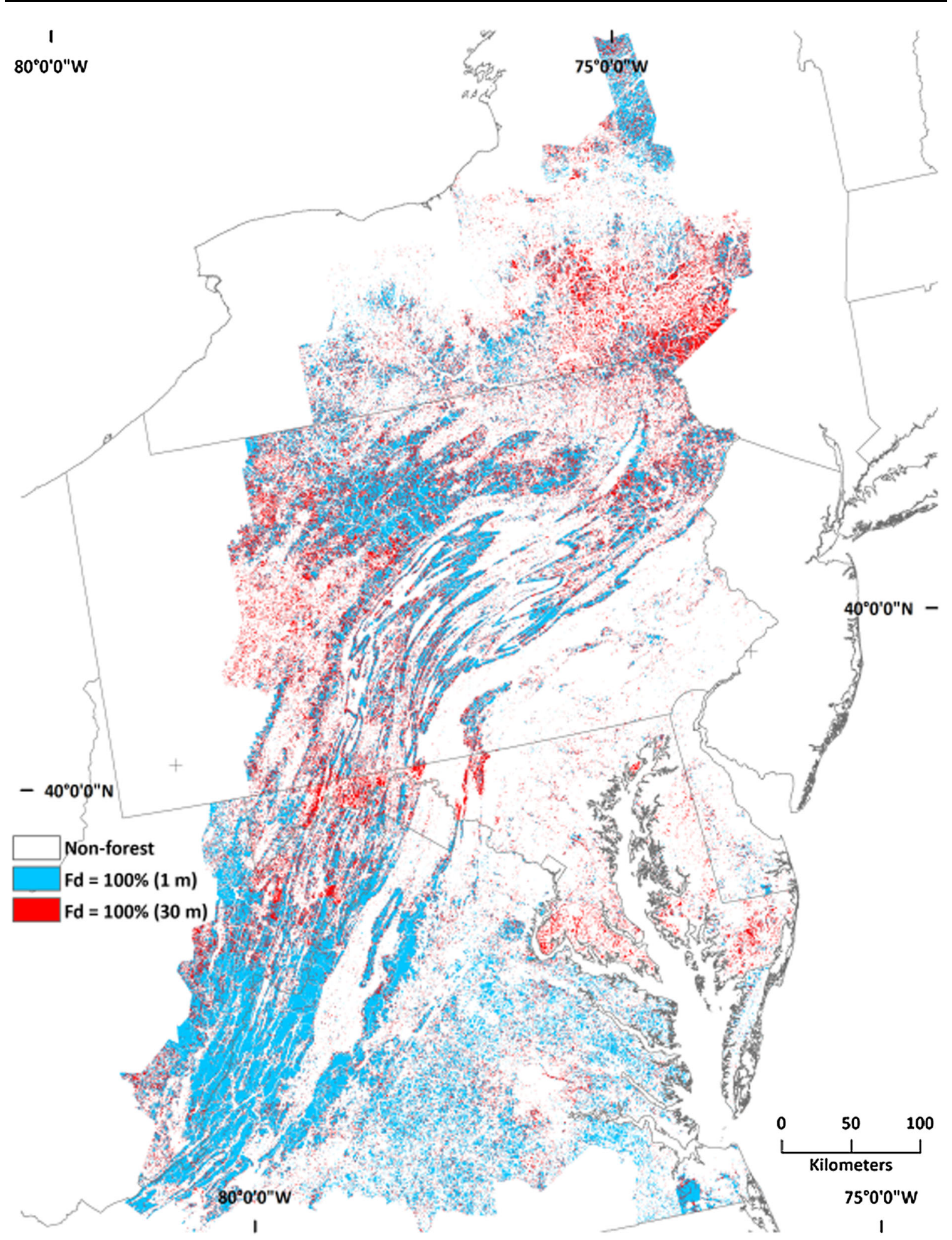

Fig. 3 Spatial distribution of intact forest (forest density $(\mathrm{Fd})=100 \%$ ) at the 7.29 -ha scale ( “ + " $=40^{\circ} \mathrm{N}, 75^{\circ} \mathrm{W} ; 40^{\circ} \mathrm{N} 80^{\circ} \mathrm{W}$ ) 


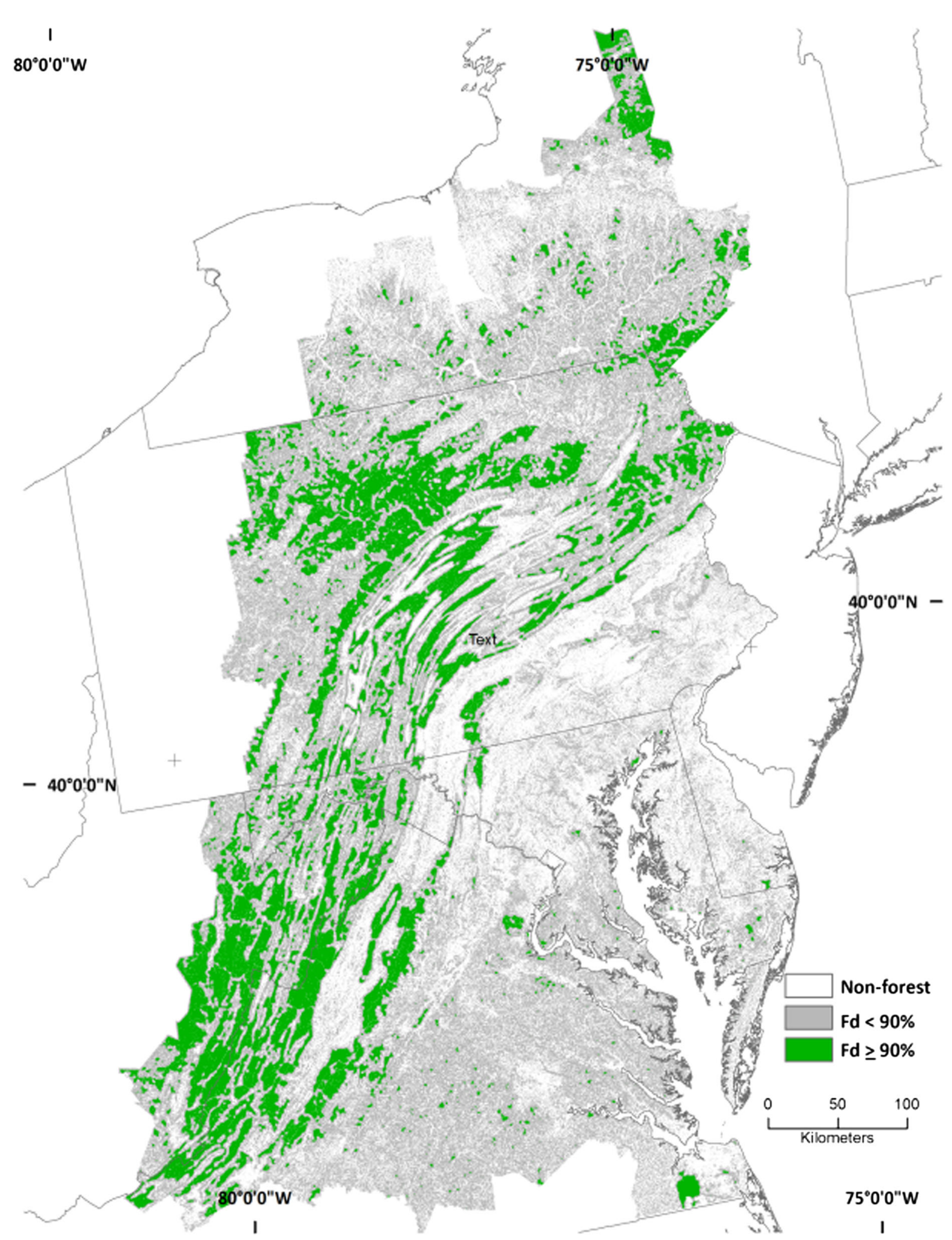

Fig. 4 Interior forest $(\mathrm{Fd} \geq 90 \%)$ from NLCD at 590.49-ha scale 


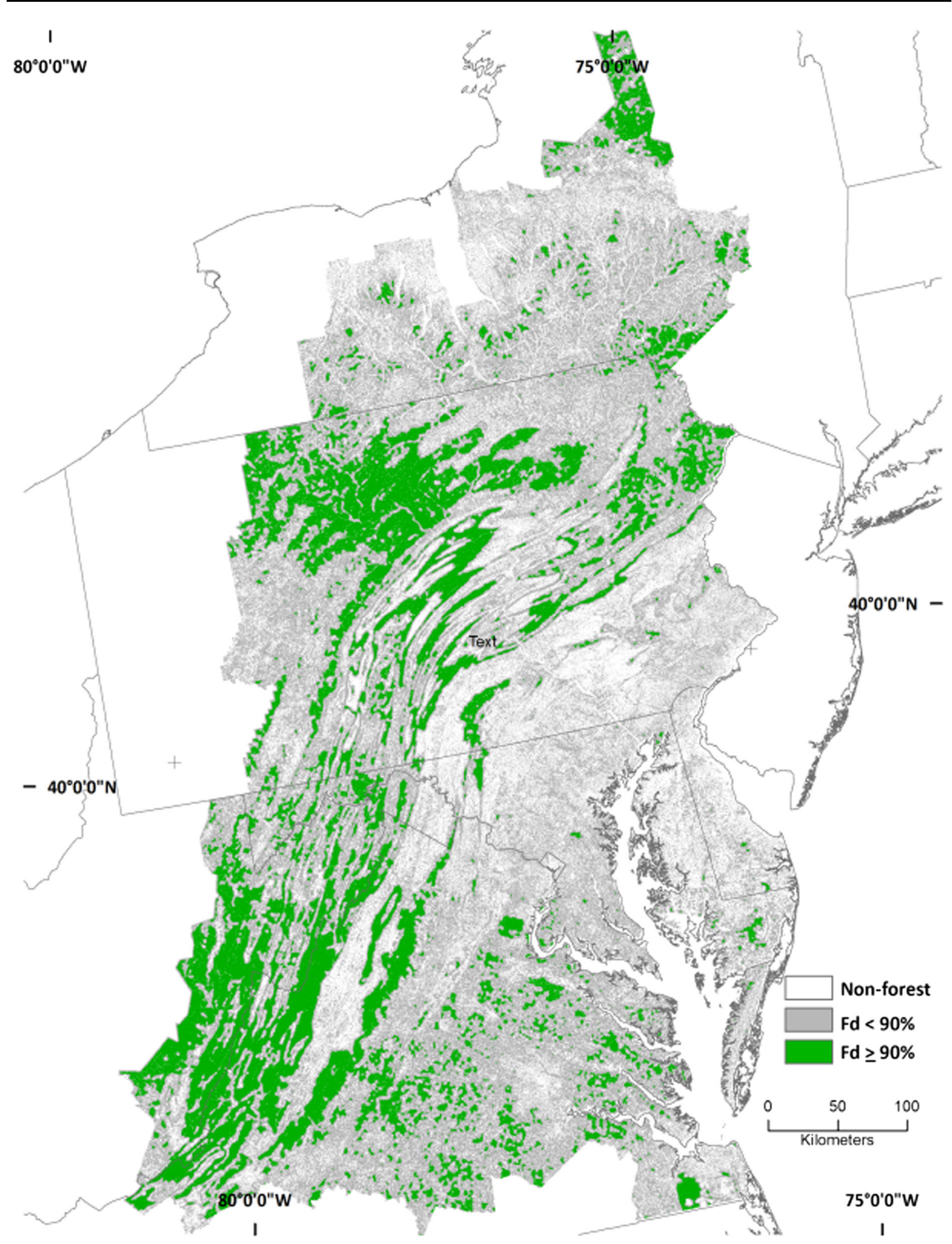

Fig. 5 Interior forest $(\mathrm{Fd} \geq 90 \%)$ from $1 \mathrm{~m}^{2}$ land cover data at 590.49-ha scale 


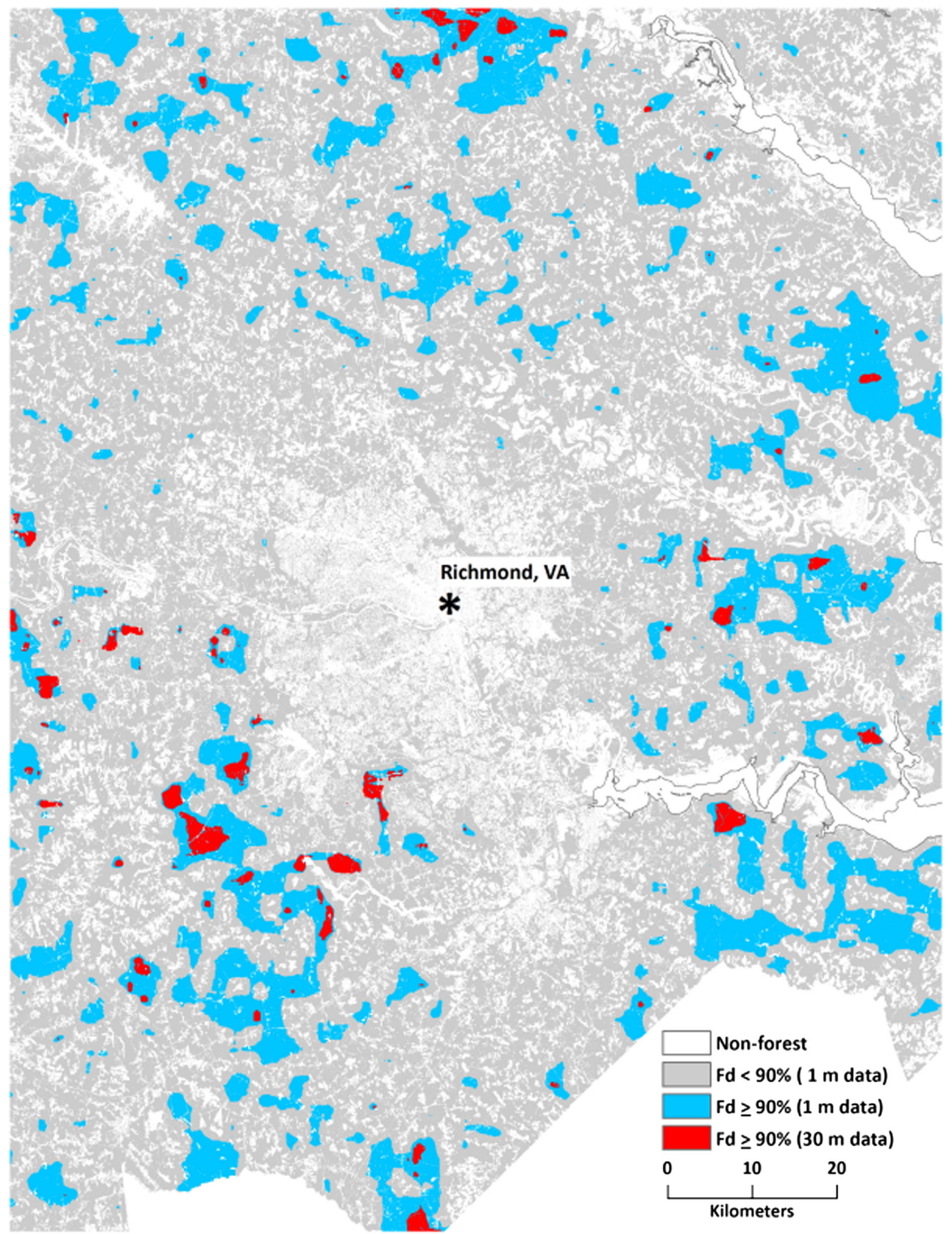

Fig. 6 Fine- and coarse-grain interior forest $(\mathrm{Fd} \geq 90 \%)$ in the vicinity of Richmond, VA 
measurement of new landscape patterns and indices. The amount of bare ground, an important indicator of rangeland condition in arid and semi-arid environments (Booth and Tueller 2003; Breckenridge and Dakins 2013), is one example of a well-established metric whose quantification would become more feasible and meaningful with higher resolution land cover data.

New applications of landscape pattern analysis are another aspect of a future landscape ecology fostered by finer grain land cover data. Urban ecology is one example where finer grain land cover data are already being used to link spatial pattern and process. Several studies that have used high-resolution land cover data have found an inverse correlation between urban vegetation and the magnitude of the Urban Heat Island (UHI) effect and human heat stress (Zhou et al. 2011; Jenerette et al. 2016; Li et al. 2016). Use of highresolution land cover in urban settings extends beyond linkages between spatial patterns of vegetation and surface temperatures, including linkages between spatial patterns of urban vegetation and spatial patterns of socio-economic factors (e.g., income, ethnicity) (Schwarz et al. 2015); mapping of grasslands around airports to identify areas suitable for alternative energy production (DeVault et al. 2012); the effect of shifting proportions of trees and grass on urban watershed management (Claggett et al. 2013; Beck et al. 2016); spatial association between urban vegetation and disease vectors (Landau and van Leeuwen 2012); and the identification of new landscape features characteristic of urban settings that are difficult to detect at the spatial resolution of Landsat (Singh et al. 2018). Some other examples of spatial pattern detection that can be undertaken with improved spatial resolution include shrub encroachment (Davies et al. 2010), bare ground identification in arid and semi-arid environments (Breckenridge and Dakins 2013), and impacts of shale gas extraction on forest spatial patterns (Drohan et al. 2012).

The interaction between spatial pattern and ecological process has been a motivating concept and a defining principle of landscape ecology (Gustafson 2018; Turner 1989). Perhaps less well recognized is the interaction between pattern and policy. What surrounds a park or refuge (landscape context) is as germane to their management as their contents (Gross et al. 2009; Jones et al. 2009). Others have also shown management of the landscape may be a more effective means of promoting forest sustainability than management of the forests themselves (Riitters et al. 2009). The differences between fine- and coarse-grain estimates of dominant, interior, and intact forest reported here are perhaps most relevant to how they might contribute to forest management and policy issues. It is possible that the more conservative, finegrain estimate of remote, roadless, intact forest (Riitters and Wickham 2003) will motivate a renewed look at preservation in the Appalachians and elsewhere. It is also possible that the improved estimates of interior forest outside that Appalachian region could motivate interest in management of forest from a landscape perspective (Thompson 2006; Riitters et al. 2009).

We searched all issues Landscape Ecology for the term NAIP, and it appeared in 19 papers. Five of the 19 papers, all published since 2016, used NAIP data as a source of land cover to examine relationships between spatial pattern and ecological processes (Berg et al. 2017; Jenerette et al. 2016; Miller et al. 2017; Shahan et al. 2017; White et al. 2018). Here, we used highresolution land cover to confirm a hypothesis about the effect of landscape grain on forest fragmentation patterns and briefly discussed the implications (management and policy relevance) of the results. We expect that future landscape analyses will rely routinely on land cover data derived from high resolution sources. The shift from Landsat-based land cover to high-resolution land cover will likely open the door to a wider range of spatial pattern-ecological process evaluations. If funding of NAIP continues, we would expect it to foster further advances landscape ecology.

Acknowledgements This document has been reviewed by the U.S. Environmental Protection Agency, Office of Research and Development, and approved for publication. The views expressed in this paper are those of the authors and do not necessarily reflect the views or policies of the US Environmental Protection Agency. We also wish to thank Don Ebert (EPA), Mike McDonald (EPA), and anonymous reviewers for their thoughtful comments on earlier versions of the paper.

Open Access This article is distributed under the terms of the Creative Commons Attribution 4.0 International License (http:// creativecommons.org/licenses/by/4.0/), which permits unrestricted use, distribution, and reproduction in any medium, provided you give appropriate credit to the original author(s) and the source, provide a link to the Creative Commons license, and indicate if changes were made. 


\section{References}

Baker WL, Cai Y (1992) The r.le programs for multiscale analysis of landscape structure using the GRASS geographical information system. Landscape Ecol 7:291-302

Beck SM, McHale MR, Hess GR (2016) Beyond impervious: urban land-cover pattern variation and implications for watershed management. Environ Manag 58:15-30

Berg MD, Wilcox BP, Simmons GS, Daugherty MP (2017) Spatiotemporal distribution of an invasive insect in an urban landscape: introduction, establishment and impact. Landscape Ecol 32:2041-2057

Booth DT, Tueller PT (2003) Rangeland monitoring using remote sensing. Arid Land Res Manag 17:455-467

Breckenridge RP, Dakins ME (2013) Evaluation of bare ground on rangelands using unmanned aerial vehicles. GISci Remote Sens 48:74-85

Brower JE, Zar JH (1977) Field and laboratory methods for general ecology. Wm. C. Brown and Company Publishers, Dubuque, IA

Butzer DW (2004) Practicing geography in a totalitarian state: (Re)casting Carl Troll as a Nazi Collaborator. Erde 135:223-231

Buyantuyev A, Wu J, Gries C (2010) Multiscale analysis of the urbanization pattern of the Phoenix metropolitan landscape of USA: time, space and thematic resolution. Landsc Urban Plan 94:206-217

Chazdon RL, Brancalion PHS, Laestadius L, Bennet-Curry A, Buckingham K, Kumar C, Moll-Rocek J, Vieira ICG, Wilson SJ (2016) When is a forest a forest? forest concepts and definitions in the era of forest and landscape restoration. Ambio 45:538-550

Claggett PR, Irani FM, Thompson RL (2013) Estimating the extent of impervious surfaces and turf grass across a large region. J Am Water Resour Assoc (JAWRA) 49:1057-1077

Corry RC, Lafortezza R (2007) Sensitivity of landscape measurement to changing grain size for fine-scale design and management. Landsc Ecol Eng 3:47-53

Davies KW, Petersen SL, Johnson DD, Davis DB, Madsen MD, Zvirzdin DL, Bates JD (2010) Estimating juniper cover from National Agriculture Imagery Program (NAIP) imagery and evaluating relationships between potential cover and environmental variables. Rangel Ecol Manag 63:630-637

DeVault TL, Belant JL, Blackwell BF, Martin JA, Schmidt JA, Wes Berger Jr L, Patterson JW Jr (2012) Airports offer unrealized potential for alternative energy production. Environ Manag 49:517-522

Drohan PJ, Brittingham M, Bishop J, Yoder K (2012) Early trends in landcover change and forest fragmentation due to shale-gas development in Pennsylvania: a potential outcome for the northcentral Appalachians. Environ Manag 49:1061-1075

Estes JE, Jensen JR, Simonett DS (1980) Impacts of remote sensing on U.S. geography. Remote Sens Environ 10:43-80

Fegeas RG, Clarie RW, Guptill SC, AndersonKE, Hallam CA (1983) Land Use and Land Cover Digital Data. U.S.
Geological Survey, Open-File Report 82-22 https://pubs. usgs.gov/of/1982/0022/report.pdf. Accessed 15 Nov 2018

Foreman RTT (1995) Land Mosaics: the ecology of landscapes and regions. Cambridge University Press, Cambridge

Forman RTT, Gadron M (1986) Landscape ecology. John Wiley \& Sons, New York

Gross JE, Goetz SJ, Cihlar J (2009) Application of remote sensing to parks and protected area monitoring: Introduction to the special issue. Remote Sens Environ 113:1343-1345

Gustafson EJ (2018) How has the state-of-the-art for quantification of landscape pattern advanced in the twenty-first century? Landscape Ecol. https://doi.org/10.1007/s10980018-0709-x

Heilman GE Jr, Strittholt JR, Slosser NC, Dellasala DA (2002) Forest fragmentation of the conterminous United States: assessing forest intactness through road density and spatial characteristics. Bioscience 52:411-422

Heinz Center (2008) The State of the Nation's Ecosystems 2008: measuring the lands, waters, and living resources of the United States. The H. John Heinz III Center for Science, Economics, and the Environment, Washington, DC

Homer C, Dewitz J, Fry J, Coan M, Hossain N, Larson C, Herold N, McKerrow A, VanDriel N, Wickham J (2007) Completion of the 2001 National Land Cover database for the conterminous United States. Photogramm Eng Remote Sens 70:829-840

Homer C, Huang C, Yang L, Wylie B, Coan M (2004) Development of a 2001 national land cover database for the United States. Photogramm Eng Remote Sens 73:337-341

Homer C, Dewitz J, Yang L, Jin S, Danielson P, Xian G, Coulston J, Herold N, Wickham J, Megown K (2015) Completion of the 2011 National Land Cover Database for the conterminous United States - representing a decade of land cover change information. Photogramm Eng Rem Sens 81:345-354

Jenerette DG, Harlan SK, Buyantuev A, Stefanov WL, DecletBarreto J, Ruddel BL, Myint SW, Kaplan S, Li X (2016) Micro-scale urban surface temperatures are related to landcover features and residential heat related health impacts in Phoenix, AZ USA. Landscape Ecol 31:745-760

Jones DA, Hansen AJ, Bly K, Doherty K, Verschuyl JP, Paugh JI, Carle R, Story SJ (2009) Monitoring land use and cover around parks: a conceptual approach. Remote Sens Environ 113:1346-1356

Jones KB, Riitters KH, Wickham J, Tankersley RD, O’Neill RV, Chaloud DJ, Smith ER, Neale AC (1997) An ecological assessment of the United States mid-Atlantic region: a landscape atlas. United States Environmental Protection Agency, Office of Research and Development EPA/600/R-97/130, Washington, DC. https://www.srs.fs. usda.gov/pubs/misc/epa_600_r-97_130.pdf. Accessed 15 Nov 2018

Kapos V (1989) Effects of isolation on the water status of forest patches in the Brazilian Amazon. J Trop Ecol 5:173-185

Landau KI, van Leeuwen WJD (2012) Fine scale spatial urban land cover factors associated with adult mosquito abundance in Tucson, Arizona. J Vector Ecol 37:407-418

Li X, Li W, Middel A, Harlan SL, Brazel AJ, Turner BL II (2016) Remote sensing of the surface urban heat island and land architecture in Phoenix, Arizona: combined effects of 
land composition and configuration and cadastral-demographic-economic factors. Remote Sens Environ $174: 233-243$

Loveland TR (2012) History of land cover mapping. In: Giri CP (ed) Remote sensing of land use and land cover. CRC Press, Taylor and Francis Group, Boca Raton, FL, pp 13-22

Loveland TR, Reed BC, Brown JF, Ohlen DO, Zhu Z, Yang L, Merchant JW (2000) Development of a global land cover characteristics database and IGBP DISCover from $1 \mathrm{~km}$ AVHRR data. Int J Remote Sens 21:1303-1330

Mandelbrot BB (1982) The fractal geometry of nature. WH Freeman, New York

McGarigal K, Marks BJ (1995) FRAGSTATS: Spatial pattern analysis program for quantifying landscape structure. U.S. Department of Agriculture, Forest Service, Pacific Northwest Research Station, General Technical Report PNWGTR-351. http://www.fs.fed.us/pnw/pubs/pnw_gtr351. pdf. Accessed 15 Nov 2018)

Miller JED, Samschen EI, Ratajczak Özdoğan M (2017) Holding the line: three decades of prescribed fires halt but do not reverse woody encroachment in grasslands. Landscape Ecol 32:2297-2310

O'Neill RV, Krummel JR, Gardner RH, Sugihara G, Jackson B, DeAngelis DL, Milne BT, Turner MG, Zygmunt G, Christensen SW, Dale VH, Graham RL (1988) Indices of landscape pattern. Landscape Ecol 1:153-162

Pallai, C., Wesson, K., 2017. Chesapeake Bay Program partnership high-resolution land cover classification accuracy assessment methodology. https://chesapeakeconservancy. org/wp-content/uploads/2017/01/Chesapeake_

Conservancy_Accuracy_Assessment_Methodology.pdf. Accessed 15 Nov 2018

Popkin G (2018) US government reviews data fees. Science $556: 417-418$

Quattrochi DA, Ridd MK (1996) Analysis of vegetation within a semi-arid urban environment using high spatial resolution airborne thermal infrared data. Atmos Environ 32:19-33

Riitters KH, O'Neill RV, Hunsaker CT, Wickham JD, Yankee DH, Timmins SP, Jones KB (1995) A factor analysis of landscape pattern and structure metrics. Landscape Ecol 10:23-39

Riitters K, Potter K, Iannone BV III, Oswalt C, Fei S, Guo Q (2018) Landscape correlates of forest plant invasions: a high-resolution analysis across the eastern United States. Divers Distrib 24:274-284

Riitters KH, Wickham J (2003) How far to the nearest road? Front Ecol Environ 1:125-129

Riitters KH, Wickham JD, Coulston JW (2004) A preliminary assessment of Montréal Process indicators of forest fragmentation for the United States. Environ Monit Assess 91:257-276

Riitters KH, Wickham JD, O'Neill RV, Jones KB, Smith ER, Coulston JW, Wade TG, Smith JH (2002) Fragmentation of continental United States forest. Ecosystems 5:815-822

Riitters KH, Wickham JD, Wade TG (2009) An indicator of forest dynamics using a shifting landscape mosaic. Ecol Ind 9:107-117

Risser PG, Karr JR, Forman RTT (1984) Landscape Ecology: Directions and Approaches, a Workshop. Illinois Natural History Survey, Special Publication Number 2,
Champaign, IL, USA. http://www.edc.uri.edu/nrs/classes/ nrs534/nrs_534_readings/RISSER.pdf (Accessed 10 October 2018)

Schwarz K, Fragkias M, Boone CG, Zhou W, McHale M, Grove JM, O’Neil-Dunne J, McFadden JP, Buckly GL, Childer D, Ogden L, Pincetl S, Pataki D, Whitmer A, Cadenasso ML (2015) Trees grow on money: urban tree canopy cover and environmental justice. PLoS ONE 10(4):e0122051

Shahan JL, Goodwin BJ, Rundquist BC (2017) Grassland songbird occurrence on remnant prairie patches is primarily determined by landscape characteristics. Landscape Ecol 32:971-988

Singh KK, Madden M, Gray J, Meentemeyer RK (2018) The managed clearing: an overlooked land-cover type in urbanizing regions? PLoS ONE 13(2):e0192822

Thompson BH (2006) Managing the working landscape. In: Goble DD, Scott JM, Davis FW (eds) The endangered species act at thirty: renewing the conservation promise, vol 1. Island Press, Washington, pp 101-126

Troll C (1939) Luftbildplan und ökologische bodenforschung. Zeitschrift der Gesellschaft fur Erdkunde zu Berlin 1939:241-298. https://www.digizeitschriften.de/dms/toc/ ?PID=PPN391365657_1939

Troll C (1971) Landscape ecology (geoecology) and biogeocenology - a terminological study. Geoforum 2(4):43-46

Turner MG (1989) Landscape ecology: the effect of pattern on process. Annu Rev Ecol Syst 20:171-197

Turner MG, O’Neill RV, Gardner RH, Milne BT (1989) Effects of changing spatial scale on the analysis of landscape pattern. Landsc Ecol 3:153-162

Vogelmann JE, Howard SM, Yang L, Larson CR, Wylie BK, Van Driel N (2001) Completion of the 1990s national land cover data set for the conterminous United States from Landsat Thematic Mapper satellite data and ancillary sources. Photogramm Eng Remote Sens 67:650-662

Vogt P, Riitters KH, Estreguil C, Kozak J, Wade TG, Wickham J (2007). Landsc Ecol 22:171-177

White MS, Tavernia BG, Shafroth PB, Chapman TB, Sanderson JS (2018) Vegetative and geomorphic complexity at tributary junctinons on the Colorado and Dolores rivers: a blueprint for riparian restoration. Landscape Ecol. https:// doi.org/10.1007/s10980-018-0734-9

Wickham J, Homer C, Vogelmann JE, McKerrow A, Mueller R, Herold ND, Coulston J (2014) The multi-resolution land characteristics (MRLC) consortium-20 years of development and integration of USA national land cover data. Remote Sens 6(8):7424-7441

Wickham J, Jones KB, Riitters KH, O’Neill RV, Tankersley RD, Smith ER, Neale AC, Chaloud DJ (1999) An integrated environmental assessment of the US mid-Atlantic region. Environ Manag 24:553-560

Wickham J, Riitters KH, Wade TG, Vogt P (2010) A national assessment of green infrastructure and change for the conterminous United States. Landsc Urban Plan 94:186-195

Wickham J, Stehman SV, Gass L, Dewitz JA, Sorensen DG, Granneman BJ, Poss RV, Baer LA (2017) Thematic accuracy assessment of the 2011 National Land Cover Database (NLCD). Remote Sens Environ 191:328-341 
Wiens JA, Milne BT (1989) Scaling of 'landscapes' in landscape ecology, or, landscape ecology from a beetle's perspective. Landscape Ecol 2:87-96

Wu J (2013) Key concepts and research topics in landscape ecology revisited: 30 years after the Allerton Park workshop. Landscape Ecol 28:1-11

Yang L, Jin S, Danielson P, Homer C, Gass L, Bender SM, Case A, Costello C, Dewitz J, Fry J, Funk M, Granneman B, Liknes GC, Rigge M, Xian G (2018) A new generation of the United States National Land Cover Database: requirements, research priorities, design, and implementation strategies. ISPRS J Photogramm Remote Sens 146:108-123
Zhou W, Huang G, Cadenasso ML (2011) Does spatial configuration matter? understanding the effects of land cover pattern on land surface temperature in urban landscapes. Landsc Urban Plan 102:54-63

Zipperer WC (1993) Deforestation patterns and their effects on forest patches. Landscape Ecol 8:177-184

Publisher's Note Springer Nature remains neutral with regard to jurisdictional claims in published maps and institutional affiliations. 